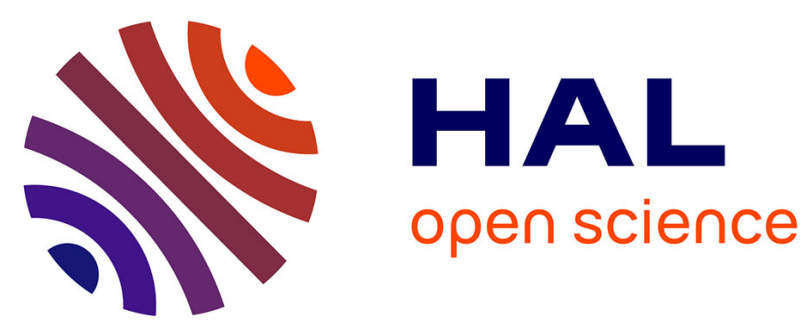

\title{
Strategy to identify the causes and to solve a sludge granulation problem in methanogenic reactors: application to a full-scale plant treating cheese wastewater
}

Hervé Macarie, Maricela Esquivel, Acela Laguna, Olivier Baron, Rachid El Mamouni, Serge R. Guiot, Oscar Monroy

\section{To cite this version:}

Hervé Macarie, Maricela Esquivel, Acela Laguna, Olivier Baron, Rachid El Mamouni, et al.. Strategy to identify the causes and to solve a sludge granulation problem in methanogenic reactors: application to a full-scale plant treating cheese wastewater. Environmental Science and Pollution Research, 2018, 25 (22), pp.21318 - 21331. 10.1007/s11356-017-9818-3 . ird-01586541v4

HAL Id: ird-01586541

https://hal.ird.fr/ird-01586541v4

Submitted on 31 Jul 2018

HAL is a multi-disciplinary open access archive for the deposit and dissemination of scientific research documents, whether they are published or not. The documents may come from teaching and research institutions in France or abroad, or from public or private research centers.
L'archive ouverte pluridisciplinaire HAL, est destinée au dépôt et à la diffusion de documents scientifiques de niveau recherche, publiés ou non, émanant des établissements d'enseignement et de recherche français ou étrangers, des laboratoires publics ou privés. 


\title{
Strategy to identify the causes and to solve a sludge granulation problem in methanogenic reactors: application to a full-scale plant treating cheese wastewater
}

\author{
Hervé MACARIE ${ }^{1 \#, ~ M a r i c e l a ~ E S Q U I V E L ~}{ }^{2}$, Acela LAGUNA ${ }^{2}$, Olivier BARON ${ }^{3}$, \\ Rachid EL MAMOUNI ${ }^{4}$, Serge R. GUIOT ${ }^{4}$, Oscar MONROY ${ }^{2}$
}

${ }^{1}$ Aix Marseille Univ, Avignon Université, CNRS, IRD, IMBE, Marseille, France

${ }^{2}$ Universidad Autónoma Metropolita-Iztapalapa, Depto Biotecnología, Mexico City, Mexico

${ }^{3}$ Lesaffre, Buenos Aires, Argentina

${ }^{4}$ National Research Council Canada, Royalmount Avenue, 6100, Montréal H4P 2R2, Canada

\section{${ }^{\#}$ Corresponding author}

Mailing address: Aix Marseille Université, Faculté des Sciences St-Jérôme, case 421, Avenue Escadrille Normandie Niemen, 13397 Marseille cedex 20.

Phone: +33491289107 / Fax: +33491288668

E-mail: herve.macarie@ird.fr

\begin{abstract}
.
Granulation of biomass is at the basis of the operation of the most successful anaerobic systems (UASB, EGSB \& IC reactors) applied worldwide for wastewater treatment. Despite of decades of studies of the biomass granulation process, it is still not fully understood and controlled. "Degranulation/lack of granulation" is a problem that occurs sometimes in anaerobic systems resulting often in heavy loss of biomass and poor treatment efficiencies or even complete reactor failure. Such a problem occurred in Mexico in two full-scale UASB reactors treating cheese wastewater. A close follow up of the plant was performed to try to identify the factors responsible for the phenomenon. Basically the list of possible causes to a granulation problem that were investigated can be classified among nutritional, i.e related to wastewater composition (e.g. deficiency or excess of macro- or micronutrients, too high COD proportion due to proteins or volatile fatty acids, high ammonium, sulfate or fat concentrations), operational (excessive loading rate, sub or over-optimal water upflow velocity) and structural (poor hydraulic design of the plant). Despite of an intensive search, the causes of the granulation problems could not be identified. The present case remains however an example of the strategy that must be followed to identify these causes and could be used as a guide for plant operators or consultants who are confronted with a similar situation independently of the type of wastewater. According to a large literature based on successful experiments at lab-scale, an attempt to artificially granulate the industrial reactor biomass through the dosage of a cationic polymer was also tested but equally failed. Instead of promoting granulation, the dosage caused a heavy sludge flotation. This shows that the scaling of such a procedure from lab- to real-scale cannot be advised right away unless its operability at such a scale can be demonstrated.
\end{abstract}

Keywords Anaerobic, cationic polymers, cheese wastewater, granulation, UASB reactor, water upflow velocity, trace metals

$\begin{array}{ll}\text { Abbreviations } \\ \text { COD } & \text { Chemical Oxygen Demand } \\ \text { D1 } & \text { Digester 1 } \\ \text { D2 } & \text { Digester 2 } \\ \text { DAF } & \text { Dissolved Air Flotation }\end{array}$




$\begin{array}{ll}E_{\mathrm{Ag} / \mathrm{AgCl}} & \text { Redox potential according to } \mathrm{Ag} / \mathrm{AgCl} \text { reference electrode } \\ \text { EGSB } & \text { Expanded Granular Sludge Bed } \\ \text { FOG } & \text { Fats Oil and Grease } \\ \text { FOG }_{\mathrm{COD}} & \text { FOG expressed as COD equivalent } \\ \text { FOG }_{\mathrm{SLR}} & \text { FOG Sludge Loading Rate } \\ \text { GLSS } & \text { Gas-Liquid-Solid Separator } \\ \text { HRT } & \text { Hydraulic Retention Time } \\ \text { HT } & \text { Homogenization (buffer) Tank } \\ \text { IC } & \text { Internal Circulation } \\ \text { LCFA } & \text { Long Chain Fatty Acids } \\ \text { OLRs } & \text { Sludge Organic Loading Rate } \\ \text { OLRv } & \text { Volumetric Organic Loading Rate } \\ \text { PW } & \text { Pumping Well } \\ \text { SRT } & \text { Solid Retention Time } \\ \text { SVI } & \text { Sludge Volumetric Index } \\ \text { TSS } & \text { Total Suspended Solids } \\ \text { VFA } & \text { Volatile Fatty Acids } \\ \text { VSS } & \text { Volatile Suspended Solids } \\ \text { Vup } & \text { Water Upflow (superficial) Velocity } \\ \text { UASB } & \text { Upflow Anaerobic Sludge Blanket }\end{array}$

\section{Introduction}

Granulation of biomass is at the basis of the operation of the most successful anaerobic systems (UASB, EGSB \& IC reactors) applied worldwide for wastewater treatment (van Lier et al. 2015). Despite of decades of studies of the biomass granulation process, it is still not fully understood and controlled (McHugh et al. 2003; Abbasi and Abbasi 2012). "Degranulation/lack of granulation" is a problem that occurs sometimes in this type of anaerobic systems resulting often in heavy loss of biomass and poor treatment efficiencies or even complete reactor failure (e.g. Clark, 1988; Maat and Gorur 1990; Grootaerd et al. 1999; Ahn et al., 2001; McHugh et al. 2006; Borzacconi et al. 2008; Li et al. 2008; Sekiguchi et al. 2015).

The causes of granulation problems observed remain uncertain in most cases. Nevertheless, the information available in the literature suggests that they can be related to nutritional or nonnutritional factors such as:

1. a deficiency or excess of some macro $(\mathrm{N}, \mathrm{P}, \mathrm{S})$ or micronutrients $(\mathrm{Fe}, \mathrm{Ni}, \mathrm{Co}, \mathrm{Mo}, \mathrm{Ca}, \mathrm{Al}, \mathrm{Na}$, $\mathrm{K}, \mathrm{Se}, \mathrm{W})$ that affect sludge growth, granule stability, or may cause their mineralization - i.e. replacement of active biomass by inorganic precipitates - (Guiot et al. 1988; Grotenhuis et al. 1991; Alphenaar et al. 1993; El Mamouni et al. 1995; Kim et al. 2004; Jeison et al. 2008; Speece 2008; Zandvoort et al. 2006, Mañas et al. 2012).

2. a high concentration of proteins, ammonium, phosphate, sulphate or sulphide (Vanderhaegen et al. 1992; Thaveesri et al. 1994; Kobayashi et al. 2015).

3. a conversion of substrates to volatile fatty acids higher than $40 \%$ of COD in the buffer tank since most VFA are poor growth inducers due to their low energetic content (Vanderhaegen et al. 1992).

4. a high concentration of fats (long chain fatty acids or triglycerides) that adsorb to the biomass inducing its flotation and possibly granule disintegration (Amaral et al. 2004; Chipasa and Medrzycka 2006).

5. the presence of toxic compounds such as those brought by the disinfectants and cleansing agents which may induce cell lysis and deteriorate granule strength (Costa et al. 2007, 2013; Zitomer et al. 2007).

6. a wastewater liquid surface tension where granule formation is thermodynamically difficult if not impossible, or selects for granules with a hydrophobic external layer allowing biogas bubbles adherence and leading to sludge washout (Thaveersi et al. 1995). 
7. "water and gas" superficial velocities within the reactors below or over the optimal ranges (e.g. $0.5-2 \mathrm{~m} / \mathrm{h}$ for water) known to favour cell adhesion (i.e. the only way for cells to resist washout in these upflow systems), but also to avoid excessive erosion of the resulting microbial particles (Arcand et al. 1994; O'Flaherty et al. 1997; Bhunia and Ghangrekar 2008).

Degranulation was identified at the anaerobic wastewater treatment plant of a cheese factory near the city of Queretaro in Mexico. During the $33^{\text {rd }}$ and $34^{\text {th }}$ months of the reactor operation, a close inspection of the plant was performed in order to determine if some of the factors $(1,2,3,4$ and 7) listed above were involved. In parallel to this investigation, an artificial granulation of the biomass was attempted by dosing the reactors with a high molecular weight cationic polymer. This endeavour was based on the excellent results of enhanced granulation obtained at lab-scale by Cail and Barford as early as 1985 and reproduced since then with success regularly in the literature with different lab-scale anaerobic systems, wastewaters and polymers (e.g. El Mamouni et al. 1998; Wang et al. 2005; Ariyavongvivat et al. 2015). The results of these surveys are the object of the present paper.

\section{Material and Methods}

\section{Description of the anaerobic treatment plant.}

The cheese factory where the treatment plant is operating generates 130 to $172 \mathrm{~m}^{3} / \mathrm{d}$ of wastewater resulting mainly from washing operations involving detergents (caustic soda or phosphoric acid based) and disinfectants (sodium hypochlorite, peracetic acid, hydrogen peroxide, iodine) and for a smaller part $\left(\sim 12 \mathrm{~m}^{3} / \mathrm{d}\right)$ from the staff toilets and showers. Whey is normally commercialized. Occasionally however, when it acidifies and cannot be sold, it is also discharged into the sewers. In order to comply with discharge limits the cheese factory constructed a wastewater treatment plant consisting of a physicochemical pre-treatment step based on dissolved air flotation to remove FOG, phosphate and suspended solids followed by a biological secondary step with two anaerobic reactors (D1 and D2) to remove dissolved COD (Fig 1). In more detail, within this scheme, the process wastewater coming from the factory passed first by a grease trap to remove the easily separable FOG in order to avoid their accumulation within the feeding pipes, then by an agitated homogenization tank with 12 hours hydraulic retention time to buffer $\mathrm{pH}$ and COD variations and finally by a DAF where aluminum sulfate and an anionic polyacrylamide polymer (Hexafloc AD40 from Technics International) were added to flocculate the FOG and TSS. Caustic soda was also added at this step in order to maintain an optimum $\mathrm{pH}$ for the flocculation. The DAF pretreated effluent was directed towards a pumping well where it was mixed with the sanitary wastewater previously treated in septic tanks in order to hydrolyze fecal material. The flow rate coming from the pumping well was then divided equally between the two digesters. These digesters corresponded to identical pre-existing circular and covered tanks (Fig. 1C) with a conic base and a working volume of $60 \mathrm{~m}^{3}$ each. They were both equipped with a 4 exit submerged feeding box located at the bottom of the vessels in order to distribute the wastewater in an upflow mode as homogenously as possible within the sludge bed. At the start of the study no gas-liquid-solid separator device was installed at the top of the reactors. Each of them had also only one single point exit of the treated water that was connected to a box intended to operate as settlers and retain part of the TSS carried with the water but without recycling to the digesters. The wastewater treated in this way was used for the watering of a plot of 5 ha, property of the company. Thanks to the homogenization tank, the wastewater treatment plant could operate 365 days per year and $24 \mathrm{~h}$ a day.

\section{Analytical procedures}

All measurements were performed on $24 \mathrm{~h}$ composite water samples. COD (closed reflux colorimetric method, 5220D), TSS and VSS (methods 2540D and 2540E), $\mathrm{pH}$ (method 4500- $\mathrm{H}^{+}$), temperature (method 2550), FOG (soxhlet extraction, method $5520 \mathrm{D}$ ) and $\mathrm{SO}_{4}{ }^{2-}$ (turbidimetric 

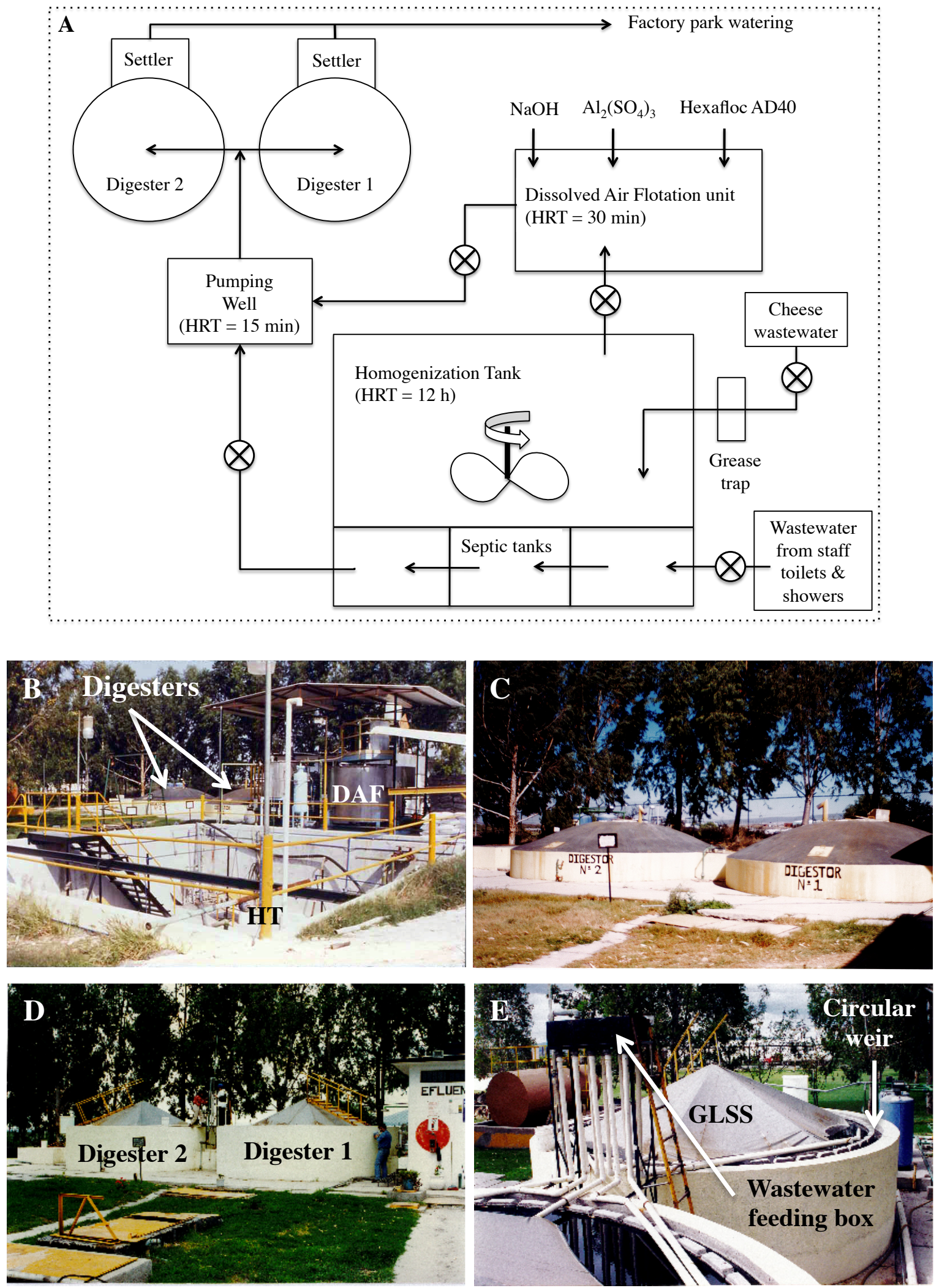

Figure 1. (A) Block process flow diagram of the cheese factory wastewater treatment plant, (B) general view of the plant with the homogenization tank in the front, the DAF system in the back right side and the two circular covered digesters before remodelling in the back left side, (C) view of the digesters before remodelling, (D) after remodelling, (E) detailed view of one of the digesters and of the wastewater feeding system (distribution box and pipes) after remodelling. 
method 4500- $\mathrm{SO}_{4}{ }^{2-}$ E) were determined according to Standard Methods (1995). Soluble COD was determined after filtration on a Whatman GF/A glass fibber membrane with porosity of 1.6 $\mu \mathrm{m}$. The concentrations of total nitrogen (including nitrate \& nitrite), total phosphorus and orthophosphate were obtained respectively with the Hach test $\mathrm{N}$ tube methods \#10022, \#10013 and \#8048. Trace metals and cations were analysed with a Perkin Elmer 500 IC plasma according to the instructions of the manufacturer. The samples for plasma analysis were prepared by microwave digestion according to EPA method 3015 for the water samples and EPA method 3051 for the sludge. Biogas $\mathrm{CH}_{4}$ and VFA in wastewater were measured according to CelisGarcía et al. (2007). The particle size distribution of the reactors' sludge was determined by manual humid sieving as described by Laguna et al. (1999) and the sludge redox potential recorded as indicated by Macarie and Guyot (1995). The SVI was measured (method 2710 D) following Standard Methods (1995) except for lab-scale reactors for which the adaptation explained by Guyot et al. (1990) was applied.

\section{Sludge methanogenic activity}

The methanogenic activity of the sludge was determined with serum bottles of $100 \mathrm{~mL}$ filled under $\mathrm{N}_{2}$ with a mixture of PW wastewater and sludge to have a COD/VSS ratio of 1 and a VSS concentration between 3-5 g/L. The bottles were incubated at $35^{\circ} \mathrm{C}$ with shaking and their gas phase was regularly sampled in order to follow the $\mathrm{CH}_{4}$ concentration. The specific activity was determined from the slope of the linear phase of methane production divided by the amount of VSS in the bottle. Methane was later converted to COD considering that $15.625 \mathrm{mmole}^{\circ} \mathrm{CH}_{4}$ are produced per $\mathrm{g}$ of COD degraded.

Table 1. Frequency and conditions of dosage of Percol 763 to the industrial reactors.

\begin{tabular}{lccccc}
\hline $\begin{array}{l}\text { Day of } \\
\text { operation }\end{array}$ & Place of dosage & $\begin{array}{c}\text { Polymer solution } \\
\text { concentration }\end{array}$ & $\begin{array}{c}\text { Duration of } \\
\text { dosage }\end{array}$ & \multicolumn{2}{c}{ Polymer Dose } \\
Reactor D1 & & $\begin{array}{c}\text { Reactor D2 } \\
\text { mg Percol 763/g sludge TSS }\end{array}$ \\
\hline 974 & Reactor top & 0.25 & $3 \mathrm{~min}$ & - & 0.24 \\
978 & Reactor top & 0.5 & $3 \mathrm{~min}$ & - & 0.23 \\
986 & Distribution box & 0.25 & $7.5 \mathrm{~h}$ & - & 1.00 \\
992 & Pumping well & 0.25 & $7 \mathrm{~h}$ & - & 0.27 \\
998 & Pumping well & 0.25 & $1.25 \mathrm{~h}$ & - & 0.10 \\
1002 & Pumping well & 0.25 & $1.5 \mathrm{~h}$ & 0.25 & 0.37 \\
1008 & Pumping well & 0.25 & $1 \mathrm{~h}$ & 0.28 & 0.12 \\
\hline
\end{tabular}

\section{Polymer addition}

The cationic polymer Percol 763 (Allied Colloids Inc., USA) used for the artificial granulation attempt as well as its discontinuous dosage to the reactors while they are in operation were selected based on the work of El-Mamouni et al. (1998). Percol 763 presents the advantage of a flocculation capacity minimally affected by $\mathrm{pH}$ in the range 2 to 10 . The dosage, necessary to obtain an optimal sludge flocculation, was predetermined through Jar tests and was found at 1 $\mathrm{mg} / \mathrm{g}$ TSS. The absence of toxicity at this concentration for the reactors' biomass was also verified. The polymer was added 7 times to the cheese factory reactor D2 in the form of a 0.25 or $0.5 \%(\mathrm{w} / \mathrm{v})$ solution in tap water. The solution was dosed at different points of the plant and the dosage was adjusted from 0.12 to $1 \mathrm{mg}$ polymer/g TSS (Table 1). Reactor D1 was initially used as control but received the final two doses of Percol 763. Originally, the dosage frequency was to 
be determined on the amount of TSS at the exit of the reactor. In reality, each polymer dosage was separated by 3 to 8 days.

\section{Results and discussion.}

Full-scale reactor start-up, detection of the granulation problem, consequences and first tentative corrective actions.

The two full-scale digesters were inoculated with the granular sludge of an anaerobic lagoon treating the wastewater of another cheese factory (Monroy et al. 1995). When wastewater was introduced, the size of the granules started to decrease. The smaller particles were washed out of the reactors resulting in a heavy loss of biomass (effluent TSS $>200 \mathrm{mg} / \mathrm{l}$ ). As a result, 19 months after the start up, almost half of the initial sludge mass had been lost and 54 to $63 \%$ of the VSS still present in the digesters corresponded to particles smaller than $0.59 \mathrm{~mm}$ (Fig. 2 see values for day 597). The sludge organic loading rate had also reached values as high as $2-3 \mathrm{~kg}$ COD $/ \mathrm{kg}$ VSS.day while the sludge methanogenic specific activity was only $0.07-0.11 \mathrm{~kg}$ COD/kg VSS.day. The SRT was less than 12-22 days. As a consequence, the reactors never reached the design performances $(75 \%$ COD removal) and presented total COD removals of only $14-20 \%$ (22-24\% for soluble COD) (Table 2, see data for reactor D1 and days 531 to 597). A reduction of the wastewater flow to reactor D2 during the same period in order to adjust its sludge organic loading rate to a more reasonable value of $1 \mathrm{~kg} C O D / \mathrm{kg}$ VSS.day had no beneficial effect on COD removal (Table 2). Despite the overload imposed to the digesters, their mixed liquors always presented an adequate $\mathrm{pH}(6.6-6.7)$ and redox potential $\left(E_{A g / A g C l}=-389 /-\right.$ $398 \mathrm{mV})$.

\section{Polymer used in DAF}

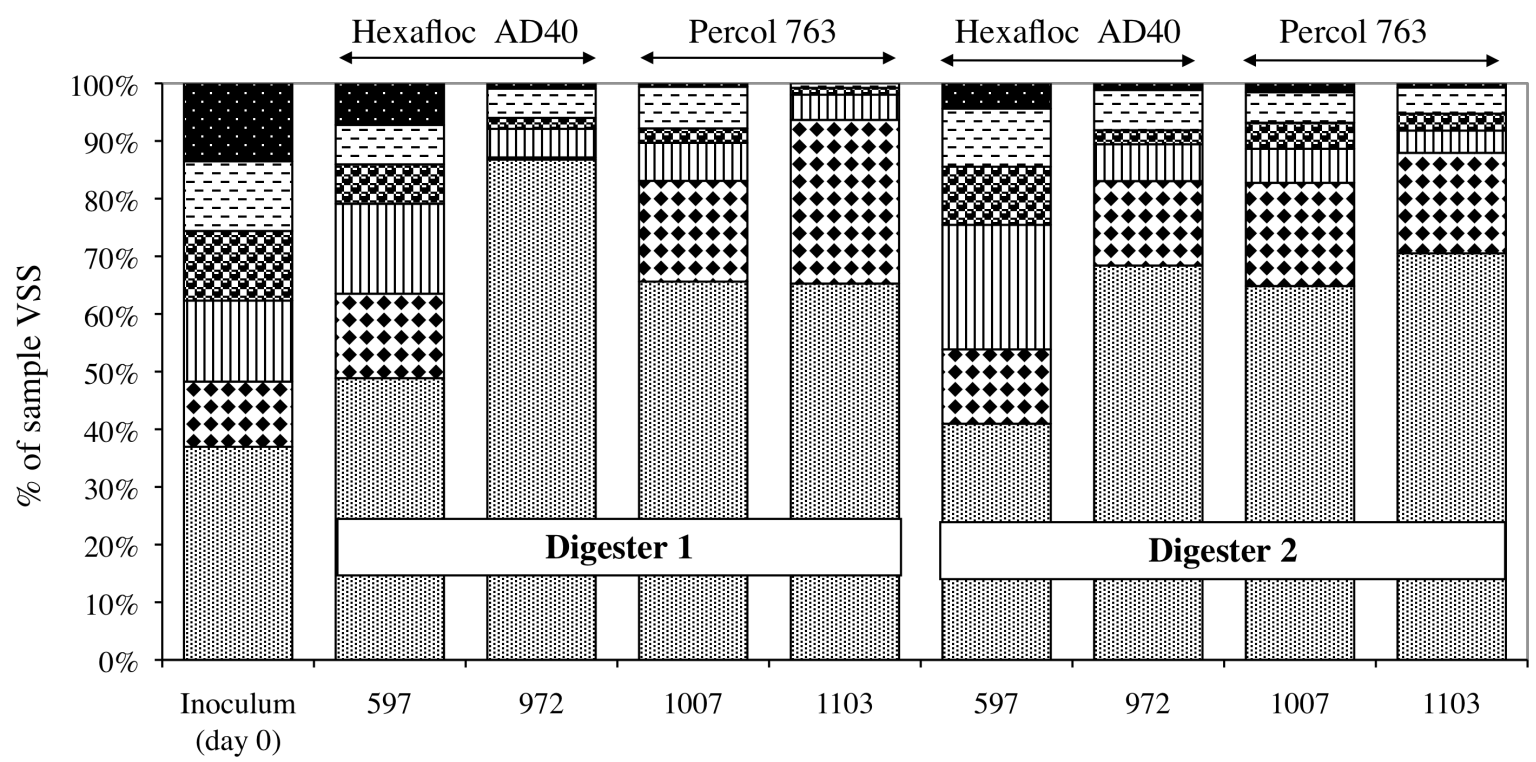

Day of sampling

\begin{tabular}{|c|c|c|}
\hline $\begin{array}{l}\text { 橉 } \mathrm{D}<0.23 \mathrm{~mm} \\
0.76<\mathrm{D}<0.925\end{array}$ & $\begin{array}{l}\square 0.23<\mathrm{D}<0.59 \\
\Xi_{0} 0.95<\mathrm{D}<2\end{array}$ & $\begin{array}{l}\mathbb{⿴ 囗 十} 0.59<\mathrm{D}<0.76 \\
\mathbf{q}_{2}<\mathrm{D}\end{array}$ \\
\hline
\end{tabular}

Figure 2. Evolution of the granulometry of reactor D1 and D2 sludge over time

In an attempt to increase the treatment plant performance, 1 year and 8 months after the start up, the anaerobic reactors were transformed into UASB systems. The reactor modification included (1) the installation of a GLSS device to improve biomass retention (new reactor working volume $88.4 \mathrm{~m}^{3}$ ), (2) the construction of a circular weir at the top of each reactor to collect homogeneously the treated water and eliminate eventual hydraulic short circuits and (3) the 
Table 2. Operating conditions and performances of the industrial reactors through days 531 to $1023(*)$.

\begin{tabular}{|c|c|c|c|c|c|}
\hline \multirow[t]{2}{*}{ Parameters } & \multirow{2}{*}{$\begin{array}{l}\text { Design } \\
\text { values }\end{array}$} & \multicolumn{4}{|c|}{ Days of operation after $1^{\text {st }}$ start-up } \\
\hline & & $531-597$ & 972 & 1008 & 1023 \\
\hline \multicolumn{6}{|l|}{ Pumping Well } \\
\hline COD total (g/L) & - & $2.78 \pm 0.59$ & 2.788 & 1.731 & 1.538 \\
\hline COD soluble (g/L) & - & $2.38 \pm 0.55$ & 2.374 & 1.355 & 1.200 \\
\hline $\mathrm{TSS}(\mathrm{g} / \mathrm{L})$ & - & $0.31 \pm 0.18$ & 0.27 & 0.17 & nd \\
\hline FOG $(\mathrm{g} / \mathrm{L})$ & - & nd & 0.359 & 0.156 & 0.156 \\
\hline \multicolumn{6}{|l|}{ Reactor D1 } \\
\hline Flow rate to the reactor $(\mathrm{L} / \mathrm{s})$ & 0.7 & $1.02 \pm 0.12$ & 0.16 & 0.31 & 0.5 \\
\hline Sludge mass (kg TSS / reactor) & - & $238.41 \pm 143.9$ & 569.07 & 535.27 & 1561.72 \\
\hline Sludge [VSS]/[TSS] (\%) & - & $46.72 \pm 16.73$ & 49.34 & 51.82 & 46.75 \\
\hline OLRv $\left(\mathrm{kg} \mathrm{COD} / \mathrm{m}^{3} \cdot \mathrm{d}\right)$ & 2 & $4.13 \pm 1.23$ & 0.44 & 0.52 & 0.75 \\
\hline OLRs (kg COD/kg VSS.d) & 0.6 & $2.99 \pm 1.21$ & 0.137 & 0.167 & 0.091 \\
\hline $\mathrm{FOG}_{\mathrm{SLR}}\left(\mathrm{g} \mathrm{FOG}_{\mathrm{COD}} / \mathrm{g}\right.$ VSS.d) & - & nd & 0.048 & 0.041 & 0.025 \\
\hline HRT (days) & 1 & $0.69 \pm 0.06$ & 6.4 & 3.3 & 2.0 \\
\hline SRT (days) & 90 & $12.03 \pm 9.72$ & 147.0 & 85.0 & 271.8 \\
\hline $\operatorname{Vup}(\mathrm{m} / \mathrm{h})$ & 0.08 & $0.128 \pm 0.015$ & 0.018 & 0.036 & 0.058 \\
\hline Total COD removal (\%) & 75 & $14.89 \pm 12.31$ & 85.30 & 69.02 & nd \\
\hline Soluble COD removal (\%) & 80 & $22.93 \pm 18.40$ & 93 & 76 & 97 \\
\hline $\mathrm{TSS}$ out $(\mathrm{mg} / \mathrm{L})$ & 70 & $225 \pm 20$ & 280 & 235 & 133 \\
\hline \multicolumn{6}{|l|}{ Reactor D2 } \\
\hline Flow rate to the reactor $(\mathrm{L} / \mathrm{s})$ & 0.7 & $0.58 \pm 0.20$ & 0.12 & 0.3 & 0.51 \\
\hline Sludge mass (kg TSS / reactor) & - & $416.39 \pm 216.93$ & 898.60 & 1267.88 & 1855.24 \\
\hline Sludge $[\mathrm{VSS}] /[\mathrm{TSS}](\%)$ & - & $36.50 \pm 14.86$ & 50.92 & 51.49 & 48.16 \\
\hline OLRv $\left(\mathrm{kg} \mathrm{COD} / \mathrm{m}^{3} \cdot \mathrm{d}\right)$ & 2 & $2.33 \pm 1.06$ & 0.33 & 0.51 & 0.77 \\
\hline OLRs (kg COD/kg VSS.d) & 0.6 & $1.01 \pm 0.21$ & 0.06 & 0.07 & 0.08 \\
\hline $\mathrm{FOG}_{\mathrm{SLR}}\left(\mathrm{g} \mathrm{FOG}_{\mathrm{COD}} / \mathrm{g}\right.$ VSS.d) & - & nd & 0.022 & 0.017 & 0.021 \\
\hline HRT (days) & 1 & $1.08 \pm 0.11$ & 8.5 & 3.4 & 2.0 \\
\hline SRT (days) & 90 & $38.93 \pm 29.88$ & 234.2 & 123.8 & 206.4 \\
\hline $\operatorname{Vup}(\mathrm{m} / \mathrm{h})$ & 0.08 & $0.07 \pm 0.03$ & 0.014 & 0.035 & 0.059 \\
\hline Total COD removal (\%) & 75 & $20.16 \pm 16.32$ & 74.46 & 67.67 & nd \\
\hline Soluble COD removal (\%) & 80 & $24.01 \pm 19.05$ & 87 & 81 & 98 \\
\hline TSS out $(\mathrm{mg} / \mathrm{L})$ & 70 & $213 \pm 153$ & 370 & 395 & 204 \\
\hline
\end{tabular}

* nd: not determined. Values after \pm correspond to standard deviation. 
replacement of the submerged wastewater distribution system by an external distribution box, from which, 5 pipes were directed to the bottom of each sludge bed $\left(1\right.$ inlet $\left./ 5.6 \mathrm{~m}^{2}\right)$ to ensure a better contact between the microorganisms and the wastewater (Fig. 1E). Once the transformations were completed 3 months later, the reactor biomass content was also increased to $30 \mathrm{~m}^{3}$ through the addition of fresh sludge from the same source as the original inoculum. The restart up strategy consisted in adjusting the digesters' feeding rate to their biomass real treatment capacity. With these modifications, the reactor performances improved drastically. On day 972 (2 years and 9 months after the $1^{\text {st }}$ start-up), they removed more than $74 \%$ and $87 \%$ of the total and soluble COD respectively (Table 2). However, until this date the flow rate that they accepted was limited to $14 \%$ of the flow rate reaching the plant $(2 \mathrm{~L} / \mathrm{s})$ and any increase of this value was immediately translated into an important biomass washout. Additionally, the sludge granulometry remained poor with 83 to $87 \%$ of the sludge VSS corresponding to sludge particles smaller than $0.59 \mathrm{~mm}$ of which at least $68 \%$ were smaller than $0.23 \mathrm{~mm}$ (Fig. 2, see day 972). It is when possible causes for the degranulation/lack of granulation started to be investigated.

\section{Search of Nutritional factors: characterization of wastewater composition}

\section{COD/N/P/S ratio}

The characterisation of the wastewater at different points of the plant (Table 3) showed that the DAF removed $71.9 \pm 19.8 \%$ of the FOG, $76.7 \pm 10.4 \%$ of the TSS, $28.2 \pm 16.7 \%$ of total nitrogen, $69 \pm 9.5 \%$ of total phosphorus and $80 \%$ of the particulate COD while soluble COD removal was almost negligible (less than 10\%). The concentrations remaining in the wastewater after mixing with the sanitary flow in PW resulted in a COD/N/P/S ratio of 100/2.3/0.95/6.58 which indicated that nitrogen, phosphorus and sulphur were respectively 1.6, 3 and 87 times in excess compared to the minimum ratio $(100 / 1.43 / 0.28 / 0.075)$ usually recommended for biomass growth and so granule formation in anaerobic digestion.

Table 3. Wastewater composition at different points of the cheese factory treatment plant from day 973 to $1033(*)$

\begin{tabular}{|c|c|c|c|c|c|c|c|c|c|c|c|}
\hline \multirow{2}{*}{$\begin{array}{l}\text { Sampling } \\
\text { point } \\
\text { (exit) }\end{array}$} & \multirow{2}{*}{$\begin{array}{l}\mathrm{T} \\
{ }^{\circ} \mathrm{C}\end{array}$} & \multirow[t]{2}{*}{$\mathrm{pH}$} & \multirow{2}{*}{$\begin{array}{l}\text { FOG } \\
\mathrm{mg} / \mathrm{L}\end{array}$} & \multirow{2}{*}{$\begin{array}{c}\text { TSS } \\
\mathrm{mg} / \mathrm{L}\end{array}$} & \multicolumn{2}{|c|}{ COD } & \multirow{2}{*}{$\begin{array}{c}\mathrm{N} \\
\text { Total } \\
\mathrm{mg} \mathrm{N} / \mathrm{L}\end{array}$} & \multicolumn{2}{|c|}{ Phosphorus } & \multirow{2}{*}{$\begin{array}{l}\mathrm{SO}_{4}^{2-} \\
\mathrm{mg} / \mathrm{L}\end{array}$} & \multirow{2}{*}{$\begin{array}{c}\text { VFA } \\
\mathrm{mg} \mathrm{O}_{2} / \mathrm{L}\end{array}$} \\
\hline & & & & & $\begin{array}{c}\text { Total } \\
\mathrm{mg} \mathrm{O}_{2} / \mathrm{L}\end{array}$ & $\begin{array}{c}\text { Soluble } \\
\mathrm{mg} \mathrm{O}_{2} / \mathrm{L}\end{array}$ & & $\begin{array}{c}\text { Total } \\
\mathrm{mg} \mathrm{P} / \mathrm{L}\end{array}$ & $\begin{array}{l}\text { Reactive } \\
\mathrm{mg} \mathrm{P} / \mathrm{L}\end{array}$ & & \\
\hline HT & $\begin{array}{l}27.8 \\
\pm 2.1\end{array}$ & $\begin{array}{c}5.4 \\
\pm 0.4\end{array}$ & $\begin{array}{c}652.2 \\
\pm 431.2\end{array}$ & $\begin{array}{c}837.1 \\
\pm 525.8\end{array}$ & $\begin{array}{l}3275.5 \\
\pm 827.2\end{array}$ & $\begin{array}{l}1766.3 \\
\pm 655.8\end{array}$ & $\begin{array}{c}67.6 \\
\pm 17.3\end{array}$ & $\begin{array}{l}55.8 \\
\pm 9.9\end{array}$ & $\begin{array}{l}49.7 \\
\pm 8.5\end{array}$ & $\begin{array}{c}36.0 \\
\pm 53.3\end{array}$ & - \\
\hline DAF & $\begin{array}{l}27.5 \\
\pm 2.1\end{array}$ & $\begin{array}{c}6.5 \\
\pm 0.6\end{array}$ & - & $\begin{array}{l}154.2 \\
\pm 71.2\end{array}$ & $\begin{array}{l}1752.2 \\
\pm 498.2\end{array}$ & $\begin{array}{c}1605.7 \\
\pm 584.1\end{array}$ & $\begin{array}{c}47.8 \\
\pm 13.3\end{array}$ & $\begin{array}{l}17.5 \\
\pm 6.3\end{array}$ & $\begin{array}{l}12.3 \\
\pm 4.3\end{array}$ & $\begin{array}{l}269.4 \\
\pm 98.8\end{array}$ & - \\
\hline PW & $\begin{array}{r}27.4 \\
\pm 1.9\end{array}$ & $\begin{array}{c}6.6 \\
\pm 0.5\end{array}$ & $\begin{array}{r}156.06 \\
\pm 149.82\end{array}$ & $\begin{array}{r}\mathbf{1 8 3 . 8} \\
\pm 58.6\end{array}$ & $\begin{array}{r}1874.3 \\
\pm 356.7\end{array}$ & $\begin{array}{l}1575.7 \\
\pm 449.0\end{array}$ & $\begin{array}{c}42.7 \\
\pm 19.3\end{array}$ & $\begin{array}{l}17.7 \\
\pm 6.2\end{array}$ & $\begin{array}{l}12.8 \\
\pm 4.6\end{array}$ & $\begin{array}{l}369.8 \\
\pm 99.7\end{array}$ & $\begin{array}{c}272.4 \\
\pm 166.0\end{array}$ \\
\hline D1 & $\begin{array}{l}23.1 \\
\pm 1.4\end{array}$ & $\begin{array}{c}7.2 \\
\pm 0.2\end{array}$ & - & $\begin{array}{l}186.9 \\
\pm 59.1\end{array}$ & $\begin{array}{l}393.8 \\
101.2\end{array}$ & $\begin{array}{c}137.3 \\
\pm 113.6\end{array}$ & $\begin{array}{c}60.4 \\
\pm 27.2\end{array}$ & $\begin{array}{l}16.9 \\
\pm 7.7\end{array}$ & $\begin{array}{l}14.7 \\
\pm 2.2\end{array}$ & $\begin{array}{c}67.3 \\
\pm 100.9\end{array}$ & $\begin{array}{c}235.4 \\
\pm 101.9\end{array}$ \\
\hline D2 & $\begin{array}{l}23.2 \\
\pm 1.4\end{array}$ & $\begin{array}{c}7.3 \\
\pm 0.1\end{array}$ & - & $\begin{array}{l}230.4 \\
\pm 98.1\end{array}$ & $\begin{array}{c}451.8 \\
\pm 111.2\end{array}$ & $\begin{array}{c}183.3 \\
\pm 128.3\end{array}$ & $\begin{array}{c}55.0 \\
\pm 11.5\end{array}$ & $\begin{array}{l}19.4 \\
\pm 5.4\end{array}$ & $\begin{array}{l}14.7 \\
\pm 2.9\end{array}$ & $\begin{array}{c}20.4 \\
\pm 31.0\end{array}$ & $\begin{array}{c}223.9 \\
\pm 151.1\end{array}$ \\
\hline
\end{tabular}

(*) T: Temperature; N: Nitrogen; Total Phosphorus = organic + mineral phosphorus; reactive phosphorus $=\mathrm{H}_{3} \mathrm{PO}_{4}+\mathrm{H}_{2} \mathrm{PO}_{4}{ }^{-}+$ $\mathrm{HPO}_{4}{ }^{2-}+\mathrm{PO}_{4}{ }^{3-}$; VFA are expressed in COD Equivalent; values after \pm correspond to standard deviation.

\section{Concentration of proteins, ammonium, phosphate, sulphate and sulphide}

The forms under which nitrogen was present in the wastewater were not investigated. Nitrogen was probably present incorporated in proteins or as free ammonium or both since, unlike most other cheese plants, nitric acid cleaning agents were not used here (Danalewich et al. 1998). As mentioned previously, both ammonium and proteins are known to negatively affect the formation 
and growth of granular sludge pellets (Thaveersi et al. 1994). This occurs however at ammonium concentrations over $1167 \mathrm{mg} \mathrm{N}-\mathrm{NH}_{4} / \mathrm{L}(\mathrm{pH}>7.4)$ or when the proteins are at a concentration which cause a COD/N ratio higher than 100/3 (Thaveersi et al., 1994), two conditions that were never reached at the level of PW (Table 3).

Most of the $\mathrm{SO}_{4}{ }^{2-}(72.8 \%)$ detected in the wastewater was introduced through the dosage of $640 \mathrm{mg} \mathrm{Al}{ }_{2}\left(\mathrm{SO}_{4}\right)_{3} / \mathrm{L}$ to the DAF. The resulting $\mathrm{COD} / \mathrm{SO}_{4}{ }^{2-}$ ratio of 5 in the pumping well indicated that sulphate reduction should be important in the reactors. This was confirmed by a substantial decrease ( 80 to $100 \%$ ) of sulphate concentration in their effluents (Table 3 ) and visually by the black colour of their biomass. In addition, sulphate reducers growing on lactate and some amino acids could be isolated from their sludge (Hernandez-Eugenio et al. 2000). Irrespective of the point of sampling in the treatment plant, 70 to $86 \%$ of the total phosphorus ( $72 \%$ in PW) corresponded to ortho-phosphate (Table 3). This was logical since $73 \%$ of the phosphorus detected in the raw wastewater could be attributed to the phosphoric acid based detergents used to clean the pasteurisation and ultrafiltration equipments of the factory.

Table 4. Concentration of some trace metals and cations at different points of the plant (in $\mathrm{mg} / \mathrm{L}$ ) and in the sludge of the reactors (in $\mathrm{mg} / \mathrm{g}$ TSS) and comparison to the expected solubility in the reactors' mixed liquor calculated from solubility products (Ksp) but also to the optimum concentrations reported for growth of methanogenic Archaea or granule formation (both in mg/L)*.

\begin{tabular}{|c|c|c|c|c|c|c|c|c|c|c|}
\hline \multirow[t]{2}{*}{ Metal } & \multicolumn{5}{|c|}{$\begin{array}{l}\text { Water sampling } \\
\text { points } \\
\text { (exit) }\end{array}$} & \multicolumn{2}{|c|}{$\begin{array}{l}\text { Reactor } \\
\text { sludge }\end{array}$} & \multicolumn{2}{|c|}{$\begin{array}{l}\text { Maximum solubility for } \\
\text { complexes with }\end{array}$} & \multirow[t]{2}{*}{$\begin{array}{l}\text { Optimum concentration } \\
\text { for growth or } \\
\text { granulation }\end{array}$} \\
\hline & HT & DAF & PW & D1 & D2 & D1 & D2 & $\mathrm{PO}^{3-} / \mathrm{HPO}_{4}{ }^{2-}$ & $\mathrm{S}^{2-}$ & \\
\hline $\mathrm{Al}$ & 1.0 & 1.2 & 1.0 & 1.1 & 1 & 11.29 & 6.7 & $8.2310^{-6}$ & $>10^{13}$ & NA \\
\hline $\mathrm{Ca}$ & 125 & 125 & 109 & 125 & 94 & 46.88 & 39.12 & $8.5-145$ & NA & $80-200^{1}$ \\
\hline $\mathrm{Co}$ & \multicolumn{5}{|c|}{$<0.006^{* *}$} & \multicolumn{2}{|c|}{$<0.00096^{* *}$} & 0.1 & $210^{-12}-610^{-8}$ & $0.00059-0.059^{2}$ \\
\hline $\mathrm{Fe}$ & 0.02 & 0 & 0.2 & 0.1 & 0.3 & 11.82 & 8.35 & NA & $910^{-6}-810^{-5}$ & $0.28-50.4^{2}$ \\
\hline K & 156 & 188 & 188 & 266 & 484 & 15.62 & 31.25 & NA & NA & $<3510^{3}$ \\
\hline Mo & \multicolumn{5}{|c|}{$<0.0079 * *$} & $<10^{-3 * *}$ & 0.00125 & NA & NA & $0.00096-0.048^{2}$ \\
\hline $\mathrm{Na}$ & 813 & 1125 & 1219 & 1141 & 1000 & 39.12 & 70.37 & NA & NA & $<4600^{3}$ \\
\hline $\mathrm{Ni}$ & 6.8 & 10 & 4.5 & 4 & 5.6 & 0.5 & 0.7 & 2.87 & $210^{-13}-410^{-6}$ & $0.0059-5^{2}$ \\
\hline
\end{tabular}

*NA: Not Applicable; the maximum solubilities were calculated at the $\mathrm{pH}$ of the reactors (Table 3) using the following equations:

[Cation] $=\left(\mathrm{Ksp} /\left[\mathrm{PO}_{4}{ }^{3-}\right]^{2}\right)^{1 / 3}$ for $\mathrm{Ca}_{3}\left(\mathrm{PO}_{4}\right)_{2}, \mathrm{Co}_{3}\left(\mathrm{PO}_{4}\right)_{2}, \mathrm{Ni}_{3}\left(\mathrm{PO}_{4}\right)_{2} ;\left[\right.$ Cation] $=\mathrm{Ksp} /\left[\mathrm{PO}_{4}{ }^{3-}\right]$ for $\mathrm{AlPO}_{4} ;$; Cation $]=\mathrm{Ksp} /\left[\mathrm{HPO}_{4}{ }^{2-}\right]$ for $\mathrm{CaHPO}_{4}, \mathrm{CoHPO}_{4} ;[$ Cation $]=\left(\mathrm{Ksp} /\left[\mathrm{S}^{2-}\right]^{3}\right)^{1 / 2}$ for $\mathrm{Al}_{2} \mathrm{~S}_{3} ;$ [Cation] $=\mathrm{Ksp} /\left[\mathrm{S}^{2-}\right]$ for $\mathrm{CoS}, \mathrm{FeS}, \mathrm{NiS}$.

The concentrations of $\mathrm{PO}_{4}{ }^{3-}, \mathrm{HPO}_{4}{ }^{2-}$ and $\mathrm{S}^{2-}$ in the reactors were calculated with the following formulas:

$\left[\mathrm{PO}_{4}^{3-}\right]=\left[\mathrm{P}_{\text {reactive in } \mathrm{PW}}\right] /\left(1+10^{(\mathrm{pKa} 1+\mathrm{pKa} 2+\mathrm{pKa} 3-3 \mathrm{pH})}+10^{(\mathrm{pKa} 2+\mathrm{pKa} 3-2 \mathrm{pH})}+10^{(\mathrm{pKa} 3-\mathrm{pH})}\right) ;\left[\mathrm{HPO}_{4}{ }^{2-}\right]=\left[\mathrm{PO}_{4}{ }^{3-}\right] / 10^{(\mathrm{pH}-\mathrm{pKa} 3)}$

$\left[\mathrm{S}^{2-}\right]=\left[\mathrm{S}_{\text {total soluble sulphide in reactors }}\right] /\left(1+10^{\left(\mathrm{pKa}^{\prime}+\mathrm{pKa2} 2^{\prime}-2 \mathrm{pH}\right)}+10^{\left(\mathrm{pKa2}^{\prime}-\mathrm{pH}\right)}\right)$

The concentration of $\mathrm{S}_{\text {total soluble sulphide in reactors }}$ was determined with the following formula adapted from Callander and Barford (1983, see equation 13 of the paper) considering that the only sulphide source was $\mathrm{SO}_{4}{ }^{2-}$ and that $100 \%$ was reduced to sulphide in the reactors, which was true most of the time. Biogas production was not measured and was estimated from the average percent removal (E\%COD) of soluble COD (CODs) in the digesters and the fact that $0.35 \mathrm{~L}$ of $\mathrm{CH}_{4}$ are formed per $\mathrm{g}$ of COD removed and that biogas usually contains $60 \% \mathrm{CH}_{4}(\mathrm{v} / \mathrm{v})$. Alfa in this formula corresponds to Henry's law constant for the equilibrium between gaseous and soluble $\mathrm{H}_{2} \mathrm{~S}$.

$\left[\mathrm{S}_{\text {total soluble sulphide in reactors }}\right]=\left[\mathrm{SO}_{4}{ }^{2-}{ }_{\text {in PW }}\right] /\left(\left(1+\left(\left[\mathrm{CODS}_{\text {in PW }}\right] *\left(\mathrm{E}^{2} \mathrm{COD}_{\text {in D1 or D2 }} / 100\right) * 0.35\right)\right) /\left(\alpha\left(1+10^{-\mathrm{pKal}^{\prime}} / 10^{-\mathrm{pH}^{2}}\right) * 0.6\right)\right)$ The Ksp for the calculations were taken from Callander and Barford (1983) and Dean (1992): $6.310^{-19}$ for AlPO $\mathrm{AP}_{4} ; 210^{-29} \& 10$ ${ }^{25}$ for $\mathrm{Ca}_{3}\left(\mathrm{PO}_{4}\right)_{2} ; 10^{-7}$ for $\mathrm{CaHPO}_{4} ; 210^{-35}$ for $\mathrm{Co}_{3}\left(\mathrm{PO}_{4}\right)_{2}, 210^{-7}$ for $\mathrm{CoHPO}_{4}, 510^{-31}$ for $\mathrm{Ni}_{3}\left(\mathrm{PO}_{4}\right)_{2}, 210^{-7}$ for $\mathrm{Al}_{2} \mathrm{~S}_{3}, 210^{-25} \& 4$ $10^{-21}$ for CoS, $10^{-18} \& 610^{-18}$ for FeS, $210^{-26} / 110^{-24} / 210^{-21} \& 3.210^{-19}$ for NiS.

pKa values $\left(25^{\circ} \mathrm{C}\right)$ and $\alpha\left(35^{\circ} \mathrm{C}\right)$ were from Callander and Barford (1983): $\mathrm{pKa} a_{1}=\mathrm{pKa}\left(\mathrm{H}_{3} \mathrm{PO}_{4} / \mathrm{H}_{2} \mathrm{PO}_{4}^{-}\right)=2, \mathrm{pKa} 2=\mathrm{pKa}$ $\left(\mathrm{H}_{2} \mathrm{PO}_{4}{ }^{-} / \mathrm{HPO}_{4}{ }^{2-}\right)=7.3, \mathrm{pKa}_{3}=\mathrm{pKa}\left(\mathrm{HPO}_{4}{ }^{2-} / \mathrm{PO}_{4}{ }^{3-}\right)=12.3, \mathrm{pKa}_{1}{ }^{\prime}=\mathrm{pKa}\left(\mathrm{H}_{2} \mathrm{~S} / \mathrm{HS}^{-}\right)=7, \mathrm{pKa}_{2}{ }^{\prime}=\mathrm{pKa}\left(\mathrm{HS}^{-} / \mathrm{S}^{2-}\right)=12.9, \alpha=1.83$. Optimum concentrations were from El Mamouni et al. (1995) ${ }^{1}$ (granulation), Speece (2008) $)^{2}$ \& Kugelman and Chin (1971) ${ }^{3}$.

** Detection limit

An excess of reactive phosphorus and $\mathrm{SO}_{4}{ }^{2-}$ could be detrimental for sludge granulation. This is related to the capacity of $\mathrm{PO}_{4}{ }^{3-}, \mathrm{HPO}_{4}{ }^{2-}$ and $\mathrm{S}^{2-}$ (product of sulphate reduction) to form poorly soluble complexes (solubility products between $10^{-7}$ to $10^{-35}$ ) with several micronutrients indispensable for the growth of methanogens $(\mathrm{Al}, \mathrm{Co}, \mathrm{Fe}, \mathrm{Ni})$ or the stability of sludge aggregates 
$\left(\mathrm{Ca}^{2+}\right)$ and which will not be or will be less accessible to the microorganisms under a precipitated form. Theoretical calculations using expected concentrations of $\mathrm{PO}_{4}{ }^{3-}, \mathrm{HPO}_{4}{ }^{2-}$ and $\mathrm{S}^{2-}$ in the anaerobic reactors and the solubility products $(\mathrm{Ksp})$ of the different predicted complexes ${ }^{1}$, suggested that the concentrations of $\mathrm{Ca}^{2+}, \mathrm{Co}^{2+}, \mathrm{Fe}^{2+}$ and $\mathrm{Ni}^{2+}$ in the mixed liquors of the reactors could be below the recommended levels (Table 4). The direct analysis of these elements showed that in fact they were all present in adequate amounts in the reactors' mixed liquors (see concentration at the reactor exit) except Co and Mo which could not be detected (Table 4). Co and Mo were also not detected in the sludge of reactor D1 while Mo was found in the sludge of reactor $\mathrm{D} 2$ but in very low amounts (Table 4 ).

An experiment was then set up to test further this apparent deficiency. It consisted to determine the methanogenic activity of reactor D2 sludge in presence of Co and Mo added separately or together at a concentration of 0.25 or $0.5 \mathrm{mg} / \mathrm{L}$. No difference in the rate of methane production was observed compared to the activity determined in absence of added metals (Fig. 3). A similar result was obtained when acetate was used as carbon source instead of wastewater (data not shown). This suggested that, although undetectable with the analytical equipment used, the levels of Co and Mo in the wastewater were sufficient for not interfering with the methanogenic capabilities of the sludge.
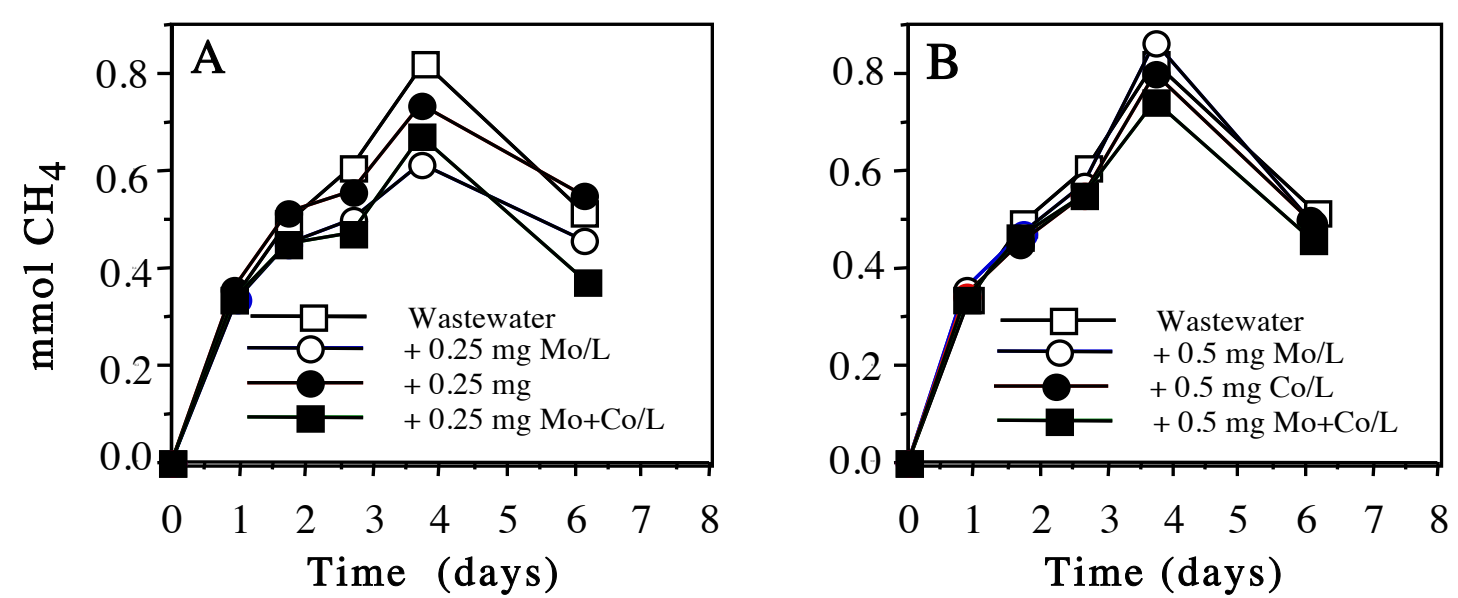

Figure 3. Evolution of the methane production of reactor D2 sludge on PW wastewater at a COD/VSS ratio of 1 in presence and absence of 0.25 (A) or $0.5 \mathrm{mg} / \mathrm{L}$ (B) of Co and Mo or both of them

Beside the capacity of $\mathrm{S}^{2-}$ to form insoluble complexes with trace metals, other product of sulphate reduction, soluble free $\mathrm{H}_{2} \mathrm{~S}$, may equally affect the granulation process since it is known to inhibit the activity of the methanogenic Archaea and acetogenic Bacteria (Rinzema and Lettinga 1988). The concentrations of soluble free $\mathrm{H}_{2} \mathrm{~S}$ in the digesters which could be calculated ${ }^{2}$ accounting for (1) a complete reduction of the $\mathrm{SO}_{4}{ }^{2-}$ present in $\mathrm{PW},(2)$ the stripping due to biogas production estimated from COD removal and (3) the $\mathrm{pH}$ of their mixed liquors, were of 42 and $36.9 \mathrm{mg} \mathrm{H} \mathrm{H}_{2} \mathrm{~S}-\mathrm{S} / \mathrm{L}$ for D1 and D2 respectively. Such $\mathrm{H}_{2} \mathrm{~S}$ levels may reduce the methanogenic acetoclastic activity by $20-30 \%$ (Rinzema and Lettinga 1988). Nevertheless, no negative effects on granulation build-up have been observed with sulphide concentrations up to $600 \mathrm{mg} / \mathrm{L}$ (Vanderhaegen et al. 1992). Even if the products of sulphate reduction $\left(\mathrm{S}^{2-}, \mathrm{H}_{2} \mathrm{~S}\right)$ have no impact on sludge granulation, the fact that sulphate-reducing bacteria may represent a big part of the microbiota could affect granular stability since the ability of these bacteria to flocculate seems very poor (Visser et al. 1993). Fortunately, for a COD/SO $4{ }^{2-}$ ratio between 5 and 10 , the impact on sludge granulation appears to be limited to a $10-20 \%$ reduction of the granule growth

\footnotetext{
$\mathrm{AlPO}_{4}, \mathrm{Al}_{2} \mathrm{~S}_{3}, \mathrm{Ca}_{3}\left(\mathrm{PO}_{4}\right)_{2}, \mathrm{CaHPO}_{4}, \mathrm{Co}_{3}\left(\mathrm{PO}_{4}\right)_{2}, \mathrm{CoHPO}_{4}, \mathrm{CoS}, \mathrm{FeS}, \mathrm{Ni}_{3}\left(\mathrm{PO}_{4}\right)_{2}, \mathrm{NiS}$

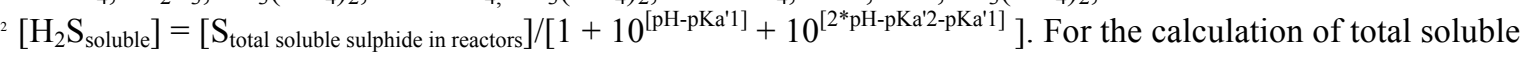
sulphide and the values of $\mathrm{pH}, \mathrm{pKa}_{1}{ }_{1}$ and $\mathrm{pKa}_{2}{ }_{2}$, see Tables $3 \& 4$.
} 
yield compared to granules grown in the same conditions but in absence of sulphate (Vanderhaegen et al. 1992) which should then be the case here.

\section{Na and $K$ content}

Due to the use of brines for cheese processing, the $\mathrm{NaCl}$ and the other salts added could negatively affect sludge growth as members of the microbiota have specific halotolerance levels, outside of which the salts become toxic or growth-arresting. Levels of sodium and potassium were followed in parallel with trace metals and calcium. Their concentrations in PW (Table 4) were at levels much lower than those known to cause $10 \%$ inhibition of the acetoclastic methanogenic activity (Kugelman and Chin 1971; Rinzema et al. 1988). Potassium was at a concentration even close to the value $(0.01 \mathrm{M}$ or $390 \mathrm{mg} / \mathrm{L})$ for which it gives an optimum antagonistic effect to the toxicity of $\mathrm{Na}^{+}$(Kugelman and Chin 1971). An increase of the ionic strength, related to the presence of these cations, could also negatively impact the physical integrity of the granules. However, it has been reported that $\mathrm{NaCl}$ concentrations of $125 \mathrm{mM}$ (2.36-fold higher than at the digester entrance) do not affect the resistance of methanogenic granules to abrasion (Pereboom 1997).

\section{VFA content}

It was found that VFA represented $15.3 \pm 11.15 \%$ of total COD and $19.7 \pm 16.9 \%$ of the soluble one at the level of PW (Table 3). With the analytical conditions used, only acetic, propionic and butyric acid could be detected. They represented respectively $47.6 \pm 6,43.4 \pm 7.6$ and $9.1 \pm 4.2 \%$ of the VFA-COD. According to previous works on acidogenesis of dairy effluents (e.g. Yu and Fang 2001), it is probable however that other compounds such as lactic acid and alcohols' (methanol, ethanol, others) were also produced in the buffer tank taking into account its $\mathrm{pH}$ (Table 3) and residence time (12 hours). Further evolution of the wastewater in the DAF and PW was not expected due to the very short hydraulic retention time here $(30 \mathrm{~min}$ and $12 \mathrm{~min}$ respectively). Lactic acid and alcohols are high-energy substrates ${ }^{3}$ and as so are good carbon sources for granulation. This means that the COD of the detected VFA, which on the contrary are poor inducers of granulation ${ }^{3}$, is sufficient to conclude that the level of acidification in the buffer tank was within the recommended range to avoid granulation problems (Lettinga and Hulshoff Pol 1991).

\section{Fats, oil and grease content}

Some $156.06 \pm 149.82 \mathrm{mg} / \mathrm{L}$ of FOG were found at the entrance of the digesters (Table 3). Most of these corresponded to milk fat not removed by the DAF and were probably in the form of triglycerides and free long chain fatty acids resulting from the expected rapid hydrolysis of the triglycerides in the homogenization tank (Hwu, 1997). The composition of the LCFA in PW was not determined, but could be approximated with that of milk which contains in $\%(\mathrm{w} / \mathrm{w})$ of total LCFA (Hwu 1997), 7\% lauric (2.72), 6\% myristic (2.807), 21\% palmitic (2.875), 6\% stearic (3.104), 2\% palmitoleic (2.834), 39\% oleic (2.894) and 13\% linoleic acids (2.82) (values in parenthesis correspond to the theoretical COD of each LCFA in $\mathrm{g} \mathrm{O}_{2} / \mathrm{g}$ ). Since the theoretical COD of the LCFA and of their corresponding triglycerides is very similar, it is possible to estimate that $1 \mathrm{~g}$ of milk LCFA or triglycerides or mixture of them generates a theoretical COD of $2.7 \mathrm{~g} \mathrm{O}_{2}\left(=\sum\left[\left(\right.\right.\right.$ LCFA $_{\mathrm{i}}$ COD $\left._{\text {theoretical }}\right) \times\left(\%\right.$ of LCFA $\mathrm{i}_{\mathrm{i}}$ in LCFA milk $\left.\left.)\right]\right)$. This means that $156.06 \pm 149.82 \mathrm{mg} / \mathrm{L}$ of FOG should represent some $421.4 \pm 404.5 \mathrm{mg} \mathrm{COD} / \mathrm{L}$. It results from this value that the FOG sludge loading rates supported by the digesters (Table 2) were well below the rate $(0.09 \mathrm{~g}$ LCFA-COD/g VSS.d) over which sludge flotation has been reported to start (Hwu et al. 1998). Moreover, this should remain true even if the digesters received all the wastewater flow from the cheese factory $\left(1 \mathrm{~L} / \mathrm{s}\right.$ or $86.4 \mathrm{~m}^{3} /$ day each). As a consequence, the levels of FOG are presumably unrelated to the observed granulation problems. Nevertheless, this cannot be

\footnotetext{
${ }^{3}$ the Gibbs free energy of their conversion to $\mathrm{CH}_{4}$ and $\mathrm{CO}_{2}$ is of $-1.145 \mathrm{~kJ} / \mathrm{g}$ COD for lactate and higher than -0.9 $\mathrm{kJ} / \mathrm{g}$ COD for the alcohols, while it is only of 0.55 and $0.56 \mathrm{~kJ} / \mathrm{g}$ COD for propionic and acetic acids, see Vanderhaegen et al. 1992
} 
definitively excluded as an almost complete washout of granular biomass has been reported in the literature (Maat and Gorur 1990) for a full scale UASB reactor treating at a similar FOG sludge loading rate $(0.028 \mathrm{~g} \mathrm{FOG} / \mathrm{g}$ TSS.d, estimated from given biomass inventory), the wastewater of a baking company containing also after pre-treatment by DAF a similar FOG concentration (136 $\mathrm{mg} / \mathrm{l})$. In this case, biomass loss could be clearly associated to FOG and solved by an improvement of FOG removal below $50 \mathrm{mg} / 1$ at the level of the DAF unit. It must be noted however that the reactor described in this study was operated at much higher volumetric loading rate $\left(6.8 \mathrm{~kg} \mathrm{COD} / \mathrm{m}^{3} . \mathrm{d}\right)$ and lower HRT (7 hours) than the present cheese factory reactors resulting in much higher water $(0.65 \mathrm{~m} / \mathrm{h})$ and biogas $(0.23 \mathrm{~m} / \mathrm{h})$ superficial velocities which would drastically increase the potential for sludge flotation and washout.

\section{Polymer addition}

The first two additions of Percol 763 resulted in the formation of a $60 \mathrm{~cm}$ layer of floating biomass at the surface of reactor D2 giving a temporary important loss of solids. This occurred despite the use of a Percol dosage (Table 1) below the optimum value identified during jar test. The problem was probably related to the trapping of biogas in the flocs and could be magnified by the place (top of the reactor) but also the duration ( $3 \mathrm{~min}$ ) of the addition. As a consequence, it was decided to add the third dose very slowly and through the reactor distribution box in order to better disperse the polymer in the sludge bed (Table 1). In spite of these modifications, the same phenomena occurred but this time the thickness of floating biomass was less $(15 \mathrm{~cm})$. The reduction of flotation was particularly significant as on this occasion the amount of Percol had been increased by a factor of 5 to reach the theoretical optimum flocculation level. Based on these results, the next 4 additions of Percol 763 were performed in PW and the doses were reduced to $0.1-0.37 \mathrm{mg}$ Percol/g TSS. The duration of the dosage was maintained between 1 and $7 \mathrm{~h}$ (Table 1). In this way, sludge flotation could be controlled and reduced to a minimum. In order to keep reactor D1 as a control, its operation was stopped during the $4^{\text {th }}$ and $5^{\text {th }}$ Percol additions. Nevertheless, the last 2 doses were distributed to both reactors (Table 1).

As shown in Fig. 4B, despite the biomass flotation described above, the addition of Percol 763 did not globally improve or worsen the loss of TSS by reactor D2 compared to reactor D1. Just, before the $7^{\text {th }}$ addition of Percol (day 1007), the measurement of the particle size distribution of the sludge of both reactors showed that no granulation had been obtained (Fig. 2). Over $60 \%$ of D2 sludge VSS still corresponded to particles smaller than $0.23 \mathrm{~mm}$ as at the beginning of the plant follow up 35 days before (day 972). The apparent improvement of D1 sludge granulometry on the same day was probably a sampling artefact. In a similar manner, over the same period, no improvement of the SVI of D2 sludge compared to D1 sludge was observed (Fig. 4C).

Following visual inspection, it appeared that the flocs obtained with Percol 763 disaggregated 2 or 3 days after being formed. This is common and usually due to the loss of stability of the polymers over time. Nevertheless, in the present case, this phenomenon was apparently the result of an antagonistic effect due to a fraction of the high molecular weight anionic polymer (Hexafloc AD40) used in the DAF unit which did not react locally and was lost to the wastewater. Qualitative experiments clearly demonstrated that D2 sludge flocculated with Percol $763(0.5 \mathrm{mg} / \mathrm{g}$ TSS) could not maintain its structure after addition of Hexafloc AD40 (0.5 $\mathrm{mg} / \mathrm{g}$ TSS).

As Percol 763 is also recommended for phosphorus removal in combination with alum, on day 998, it was decided to use it instead of Hexafloc AD40 in the DAF operation. Quickly after this change, it was possible to increase the flow rate of wastewater to the reactors without observing any biomass washout or deterioration of their COD removal efficiencies (Fig. 4A, 4B, 4D). The DAF COD, FOG, TSS, phosphorus and nitrogen removal efficiencies remained unaffected by the change of polymer (Fig. 4D, 4E). Two more additions of Percol 763 to PW were still done after day 998 (Table 1). One week after the second addition, D2 sludge became suddenly bulkier with a SVI of $80 \mathrm{~mL} / \mathrm{g}$ TSS (normal range $20-30 \mathrm{~mL} / \mathrm{g}$; Fig. 4C). No clear 


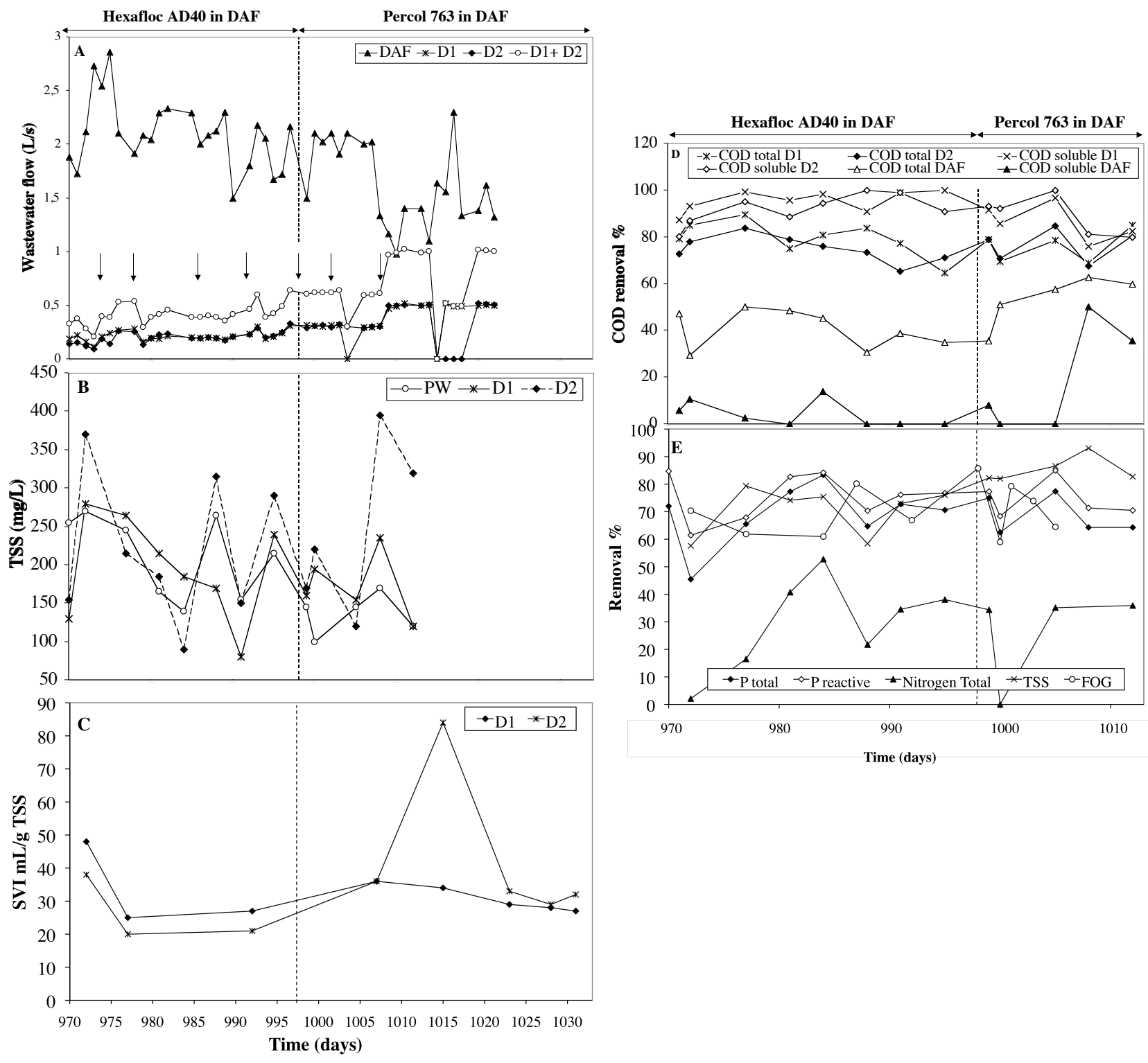

Figure 4. Effect of Percol 763 addition on: (A) the flow rate which can be fed to the reactors, (B) their TSS loss, (C) the SVI of their biomass, (D) their COD removal efficiencies together with that of the DAF and (E) the DAF phosphorus, nitrogen, TSS and FOG removal efficiencies. The arrows in A correspond to the addition of Percol directly to D2 and later D1 
explanation to this phenomenon was identified but the decision was taken to stop the direct dosage of Percol to the digesters.

At the end of the period of study (day 1033), both reactors were treating $79.1 \pm 12.4 \%$ of the total wastewater flow produced by the factory. The activities of D1 and D2 sludge measured on day $1007(0.601 \pm 0.03$ and $0.417 \pm 0.032 \mathrm{~g} \mathrm{COD} / \mathrm{g}$ VSS.d for reactors D1 and D2 respectively), showed nevertheless that the reactors had the capacity to treat the daily COD load remaining after the physicochemical pre-treatment. In agreement with this, according to the cheese factory staff, the reactors were finally able to treat the nominal flow rate. The last granulometry determination performed on day 1103, indicated however that 3 months after the switch of polymers in the DAF, the reactors' biomass was still flocculent (Fig. 2). This was unchanged after one year of operation using these new conditions (see values for the inoculum on Fig. 5).

\section{Test of the effect of water upflow velocity on granulation at lab-scale.}

The Vup of the cheese factory reactors (Table 2) being well below the range $(0.5-2 \mathrm{~m} / \mathrm{h})$ recommended for granulation (Arcand et al. 1994), and this parameter being relatively easy to manipulate at full-scale by recycling part of the treated water, two lab-scale UASB reactors of 2 litres were set up in order to evaluate if an action on this parameter could induce granulation. The test was not done at full scale because no recirculation facilities had been planned in the original design of the reactors and because no pumps of the required capacity were available on site. Logically, their purchase would be only considered in case of success of the experiment. The two lab-scale reactors were inoculated with the sludge of reactor D2 and fed with PW wastewater. Before start-up, the ratio "sludge volume/reactor working volume" was of $50 \%$ as in the full-scale reactors. The HRT (2 days) and the OLRs $(0.05-0.15 \mathrm{~kg}$ COD $/ \mathrm{kg}$ VSS.day) applied to both reactors throughout the experiment were identical to those of the real plant but one was operated at a Vup of $0.5 \mathrm{~m} / \mathrm{h}$ and the other at the Vup of the full-scale reactors $(0.06 \mathrm{~m} / \mathrm{h}$ on day 1023$)$. Such Vup were achieved by water recycling. A Vup higher than $0.5 \mathrm{~m} / \mathrm{h}$ could not be tested since this resulted in a too high expansion of the sludge bed, which reached the GLSS device.

The two lab-scale reactors presented very similar performances (data not shown). The main difference between the two reactors was that, logically, the one operated at the higher Vup showed a slightly higher loss of suspended solids to the effluent than the other $(53 \pm 94$ against $37 \pm 41 \mathrm{mg}$ TSS$/ \mathrm{L}$ ). In both cases, the loss of TSS was however 5 to 6 times lower than that observed at full-scale while the COD removal was improved by 10 to $20 \%$. The differences between the lab- and full-scale reactors were probably the result of the higher temperature at which the lab-scale experiment was performed $\left(33.5\right.$ against $\left.23^{\circ} \mathrm{C}\right)$ but were considered not so important as to affect the analysis of the increase of the upflow velocity on the granulation process and its transposition to full-scale.

The biomass of the reactor operated at $0.06 \mathrm{~m} / \mathrm{h}$ did not show a positive evolution of its particle size distribution. Only a slight segregation of the particles within the sludge bed could be immediately noticed, the biggest granules being logically in higher amounts at the bottom of the reactor (data not shown).

The reactor operated at $0.5 \mathrm{~m} / \mathrm{h}$ presented also a segregation by size of the granules within its sludge bed, but much more noticeable than previously (Fig 5). A positive evolution of the sludge particle size distribution was observed initially. For instance, on day 54 of operation, less than $40 \%$ of the sludge TSS corresponded to particles smaller than $0.23 \mathrm{~mm}$ at the bottom of the reactor, while they represented almost $80 \%$ of the TSS in the inoculum. Nevertheless, for the next sampling performed on day 70 , the sludge particle size distribution had returned to the values found on day 22 (Fig. 5). On the same way, the granulometry of the sludge at the top of the reactor, which had improved during the 42 first days of operation started to deteriorate in the subsequent samplings. This deterioration occurred after a change in the quality of the wastewater used to feed the reactors which presented a higher content of organic matter (3000-4000 mg $\mathrm{COD} / \mathrm{L}$ against $800 \mathrm{mg} / \mathrm{L}$ ) as well as a thin layer of floating material with an oily appearance. 


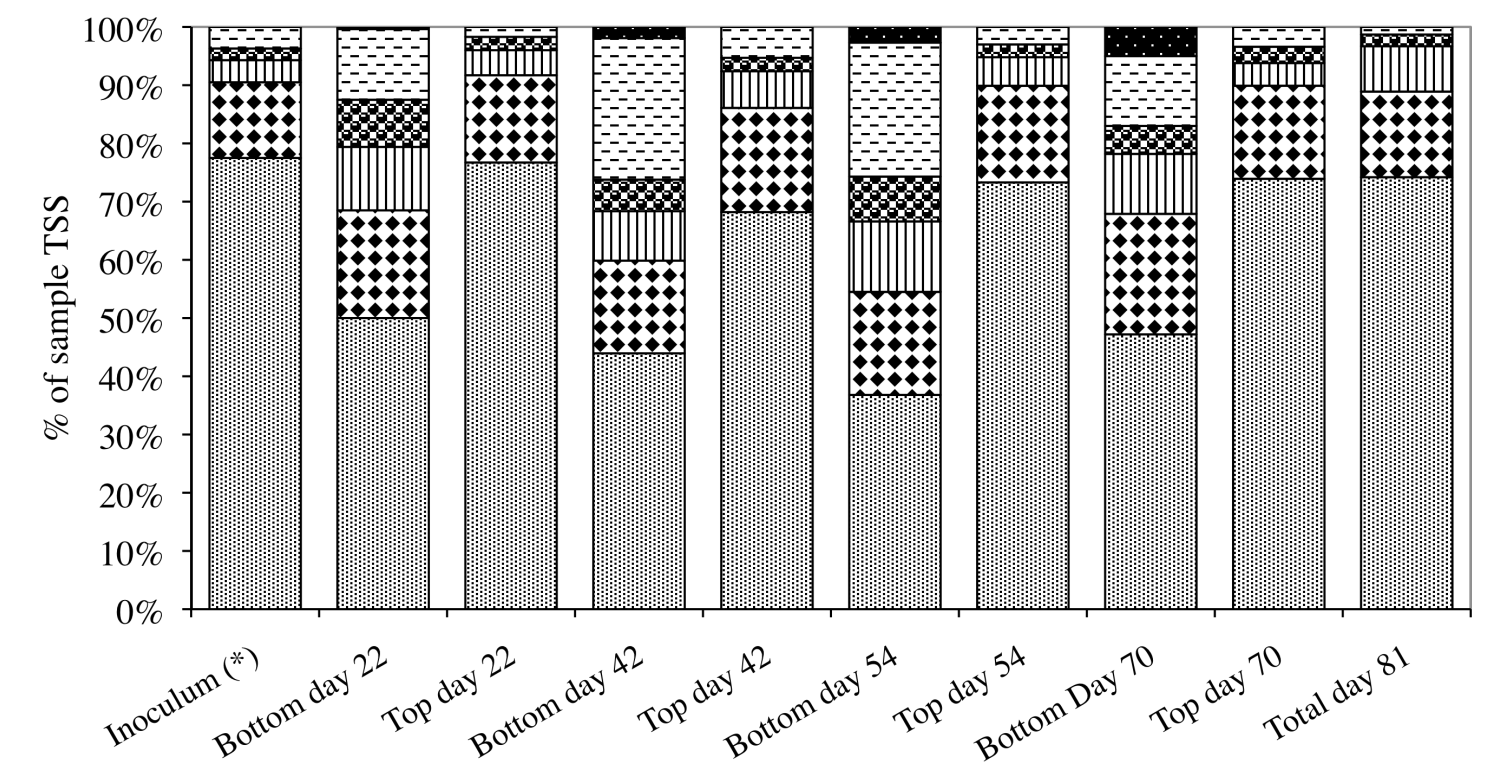

\begin{tabular}{|c|c|c|}
\hline $2<\mathrm{D}$ & $\Xi^{\Xi} .95<\mathrm{D}<2$ & $\mathbb{2}_{0.76}<\mathrm{D}<0.925$ \\
\hline $\mathbb{\square} 0.59<\mathrm{D}<0.76$ & $\oplus_{0.23}<\mathrm{D}<0.59$ & $\mathrm{D}<0.23 \mathrm{~mm}$ \\
\hline
\end{tabular}

Figure 5. Evolution of the sludge granulometry of the lab-scale reactor operated at $0.5 \mathrm{~m} / \mathrm{h}$ (*sludge sampled on reactor D2 on day 1344).

After 81 days, both reactors were emptied and their sludge beds were homogenised for a last granulometry determination. Surprisingly, no differences were observed. In addition, their particle size distributions remained almost identical to the initial one as well as their SVI (28.9 and $27.4 \mathrm{~mL} / \mathrm{g}$ TSS for the reactors operated at 0.5 and $0.06 \mathrm{~m} / \mathrm{h}$ against $26.5 \mathrm{~mL} / \mathrm{g}$ for the inoculum). The length of the experimentation (almost 12 weeks) could possibly be too short to see any positive effect of an increase of the upflow velocity. Ten weeks had been however sufficient for a similar study performed with crushed granular sludge and sucrose, an easily biodegradable compound, as substrate (Arcand et al. 1994). At least this experiment showed that an increase of the upflow velocity had no detrimental effect on the performances of the reactors and the granulometry of their sludge.

\section{Concluding remarks and perspectives}

The factors responsible of the disintegration/lack of granulation in the present case study could not be identified although the role of milk fat not removed in the DAF pre-treatment could not be completely discarded. It was shown that the granulation problem was not related to (1) a deficiency or excess of some macro- or micronutrients, (2) a high proportion of COD due to proteins or volatile fatty acids, (3) a high concentration of ammonium, (4) a high development of sulphato-reduction and (5) a sub-optimum selection pressure due to a low water upflow velocity.

The initiative to artificially granulate the sludge through the addition of a cationic polymer failed and instead caused a heavy sludge flotation. This shows that despite the excellent results reported in the literature at lab-scale since 3 decades, it is premature to advise the dosage of such polymers to promote sludge granulation in running (biogas producing) full-scale UASB-like reactors. Their use should be accepted only if successful reports on their application at full scale and detailed procedures for their dosage become available. A more promising way to induce granulation with polymers may correspond to a process similar to the one patented by Biothane (Frankin and de Pijper 2007). In this process, the sludge is pre-granulated outside the reactor through the addition of an organic cationic polymer followed by the addition of an inorganic anionic polymer plus some additives (activated carbon, calcium, etc). Published results suggest 
that the granules obtained in such a way have excellent settling properties and keep their integrity (no degranulation) in the long-term operation of UASB reactors (Jeong et al. 2005).

Despite of being limited to a specific case, the present work has a broader perspective since it gives an example of most of the points that must be investigated when a granulation problem occurs, an example that is true for any type of wastewaters.

In the case under study, at the end of the survey, the lack of granulation was not a problem anymore since the SRT of the remodelled reactors was higher than 100 days (Table 2). This means that contrarily to the beginning they had acquired an excellent capacity to retain the flocculent biomass, a capacity associated to stable and high COD removal.

\section{Acknowledgements.}

For this study, Maricela Esquivel was financially supported by the cheese factory and Acela Laguna and Olivier Baron by IRD. The authors thank the cheese factory and particularly its employees Paulino Rivas, Gerardo Gonzalez, Omar Reyes, and Abelardo Villareal for their interest and kind assistance during the realisation of this project. They also thank Sébastien Prunier and Graciela Famá for technical help at the early stage of the work, Germán Buitrón and Ilangovan Kuppusamy for the loan of a Hach spectrophotometer and a jar test equipment respectively and Mark Spanevello for help with English language.

\section{References}

Abbasi T, Abbasi SA (2012) Formation and impact of granules in fostering clean energy production and wastewater treatment in upflow anaerobic sludge blanket (UASB) reactors. Renew Sustain Energ Rev, 16:1696-1708

Ahn Y-H, Min K-S, Speece RE (2001) full scale UASB reactor performances in the brewery industry. Environ Technol 22:463-476

Alphenaar PA, Sleyster R, De Reuver P, Ligthart GJ, Lettinga G (1993) Phosphorus requirement in high rate anaerobic wastewater treatment. Water Res 27:749-756

Amaral AL, Pereira MA, Da Motta M, Pons MN, Mota M., Ferreira EC, Alves MM (2004) Development of image analysis techniques as a tool to detect and quantify morphological changes in anaerobic sludge: II. Application to a granule deterioration process triggered by contact with oleic acid. Biotechnol Bioeng 87:194-199

Arcand Y, Guiot SR, Desrochers M, Chavarie C (1994) Impact of the reactor hydrodynamics and organic loading on the size and activity of anaerobic granules. Chem Eng J 56:B23-B35

Ariyavongvivat E, Suraraksa B, Chaiprasert P (2015) Physicochemical and biological characteristics of enhanced anaerobic microbial granulation by synthetic and natural cationic polymers. Energy Procedia 79:851-858

Bhunia P, Ghangrekar MM (2008) Influence of biogas-induced mixing on granulation in UASB reactors. Biochem Eng J 41:136-141

Borzacconi L, López I, Passeggi M, Etchebehere C, Barcia R (2008) Sludge deterioration in a full scale UASB reactor after a $\mathrm{pH}$ drop working under low loading conditions. Wat Sci Tech 57:797-802

Cail RG, Barford JP (1985) The development of granulation in an upflow floc digester and an upflow anaerobic sludge blanket digester treating cane juice stillage. Biotechnol Lett 7:493498

Callander IJ, Barford JP (1983) Precipitation, chelation, and the availability of metals as nutrients in anaerobic digestion. I. Methodology, II. Applications. Biotechnol Bioeng 25:1947-1972

Celis-Garcia LB, Razo-Flores E, Monroy O (2007) Performance of a down-flow fluidized-bed reactor under sulfate reduction conditions using volatile fatty acids as electron donors. Biotechnol Bioeng 97:771-779

Chipasa KB, Medrzycka K (2006) Behaviour of lipids in biological wastewater treatment processes. J Ind Microbiol Biotechnol 33:635-645 
Clark JN (1988) Anaerobic digestion of whey in a pilot-scale upflow anaerobic sludge blanket digester. In: Tilche A and Rozzi A (eds) Poster-Papers of the $5^{\text {th }}$ International Symposium on Anaerobic Digestion. Monduzzi Editore, Bologna, Italy, pp 489-493

Costa, JC, Abreu AA, Ferreira EC, Alves MM (2007) Quantitative image analysis as a diagnostic tool for monitoring structural changes of anaerobic granular sludge during detergent shock loads. Biotechnol Bioeng 98:60-68

Costa JC, Mesquita DP, Amaral AL, Alves MM, Ferreira EC (2013) Quantitative image analysis for the characterization of microbial aggregates in biological wastewater treatment: a review. Environ Sci Pollut Res 20:5887-5912

Danalewich JR, Papagiannis TG, Belyea RL, Tumbleson ME, Raskin L (1998) Characterization of dairy waste streams, current treatment practices, and potential for biological nutrient removal. Water Res 32:3555-3568

Dean JA (1992) Lange's Handbook of Chemistry. $14^{\text {th }}$ ed. McGraw Hill, New York, USA, pp 8.6-8.11

El Mamouni R, Guiot S, Mercier R, Safi B, Samson R (1995) Liming impact on granules activity of the multiplate anaerobic reactor (MPAR) treating whey permeate. Bioprocess Eng 12:47-53

El Mamouni R, Leduc R, Guiot SR (1998) Influence of synthetic and natural polymers on the anaerobic granulation process. Wat Sci Tech 38(8-9):341-347

Frankin RJ, de Pijper MAM (2007) Process for producing granular biomass. WO Patent 2007/089144 A1, 10 pages

Grootaerd H, Defour D, Demeulemaere J, Simoens F (1999) Full-scale experience with anaerobic treatment of dairy wastewater at Belgomilk-Langemark. Med Fac Landouww Univ. Gent 64/5a:53-58

Grotenhuis JTC, van Lier JB, Plugge CM, Stams AJM, Zehnder AJB (1991) Effect of ethylene glycol-bis( $\beta$-aminoethyl ether)-N,N-tetraacetic acid (EGTA) on stability and activity of methanogenic granular sludge. Appl Microbiol Biotechnol 36:109-114

Guiot SR, Gorur SS, Kennedy KJ (1988) Nutritional and environmental factors contributing to microbial aggregation during upflow anaerobic sludge bed-filter (UBF) reactor start-up. In: Hall ER and Hobson PN (eds) Anaerobic Digestion 1988, Proceedings $5^{\text {th }}$ International Symposium, Pergamon Press, London, UK, pp 47-53

Guyot JP, Macarie H, Noyola A (1990) Anaerobic digestion of a petrochemical wastewater using the UASB process. Appl Biochem Biotechnol 24/25:579-589

Hernandez-Eugenio G, Fardeau ML, Patel BKC, Macarie H, Garcia JL, Ollivier B (2000) Desulfovibrio mexicanus sp. nov., a sulfate-reducing bacterium isolated from an upflow anaerobic sludge blanket (UASB) reactor treating cheese wastewaters. Anaerobe 6:305-312.

Hwu CS (1997) Enhancing anaerobic treatment of wastewaters containing oleic acid. PhD thesis, University of Wageningen, The Netherlands, ISBN 90-5485-733-1

Hwu CS, Tseng SK, Yuan CY, Kulik Z, Lettinga G (1998) Biosorption of long-chain fatty acids in UASB treatment process. Water Res 32:1571-1579

Jeison D, Del Rio A, van Lier JB (2008) Impact of high saline wastewaters on anaerobic granular sludge functionalities. Wat Sci Tech 57(6):815-819.

Jeong HS, Kim YH, Yeom SH, Song BK, Lee DI (2005) Facilitated UASB granule formation using organic-inorganic hybrid polymers. Proc Biochem 40:89-94

Kim YH, Yeom SH, Ryu JY and Song BK (2004) Development of a novel UASB/CO ${ }_{2}$-stripper system for the removal of calcium ion in paper wastewater. Proc Biochem 39:1393-1399

Kobayashi T, Xu KQ, Chiku H (2015) Release of extracellular polymeric substance and disintegration of anaerobic granular sludge under reduced sulfur compounds-rich conditions. Energies 8:7968-7985

Kugelman IJ, Chin KK (1971) Toxicity, synergism and antagonism in anaerobic waste treatment processes. Adv Chem Ser 105:55-90

Laguna A, Ouattara A, Gonzalez RO, Baron O, Famá G, El Mamouni R, Guiot S, Monroy O, Macarie H (1999) A simple and low cost technique for determining the granulometry of upflow anaerobic sludge blanket reactor sludge. Wat Sci Tech 40(8):1-8 
Lettinga G, Hulshoff Pol LW (1991) UASB-process design for various types of wastewaters. Wat Sci Tech 24(8):87-107

Li J, Hu B, Zheng P, Qaisar M, Mei L (2008) Filamentous granular sludge bulking in a laboratory scale UASB reactor. Bioresource Technol. 99:3431-3438

Maat DZ, Gorur SS (1990) Start-up and performance testing of a full scale UASB anaerobic wastewater treatment facility. In: Proceedings 44th Industrial Waste Conference, Purdue University, Lewis Publishers Inc, Chelsea, MI, USA, pp 209-214

Macarie H, Guyot JP (1995) Use of ferrous sulphate to reduce the redox potential and allow the start-up of UASB reactors treating slowing biodegradable compounds: application to a wastewater containing 4-methylbenzoic acid. Environ Technol 16:1185-1192

Mañas A, Spérandio M, Decker F, Biscans B (2012) Location and chemical composition of microbially induced phosphorus precipitates in anaerobic and aerobic granular sludge. Environ Technol 33:2195-2209.

McHugh S, Collins G, O'Flaherty V (2006) Long-term, high rate anaerobic biological treatment of whey wastewaters at psychrophilic temperatures. Biores Technol 97:1669-1678

McHugh S, O'Reilly C, Mahony T, Colleran E, O'Flaherty V (2003) Anaerobic granular sludge bioreactor technology. Rev Environ Sci Bio/Technol 2:225-245

Monroy O, Vázquez F, Derramadero JC, Guyot JP (1995) Anaerobic-aerobic treatment of cheese wastewater with national technology in Mexico: the case of «El Sauz». Wat Sci Tech 32(12):149-156

O'Flaherty V, Lens PNL, De Beer D, Colleran E (1997) Effect of feed composition and upflow velocity on aggregate characteristics in anaerobic upflow reactors. Appl Microbiol Biotechnol 47:102-107

Pereboom JHF (1997) Strength characterisation of microbial granules. Wat Sci Tech 36(6-7):141148.

Rinzema A, Lettinga G (1988) Anaerobic treatment of sulfate containing wastewater. In: Wise DL (ed) Biotreatment Systems, Vol. III, CRC Press, Boca Raton, Florida, USA, pp 65-109

Rinzema A, van Lier J, Lettinga G (1988) Sodium inhibition of acetoclastic methanogens in granular sludge from a UASB reactor. Enz Microb Technol 10:24-32

Sekiguchi Y, Ohashi A, Parks DH, Yamauchi T, Tyson GW, Hugenholtz P (2015) First genomic insights into members of a candidate bacterial phylum responsible for wastewater bulking. PeerJ 3:e740. doi: 10.7717/perrj.740

Speece RE (2008) Anaerobic biotechnology and odor/corrosion control for municipalities and industries. chapter 16, trace metals. Archae Press, Nashville, Tennessee, USA, pp 405-430

Standard Methods for the Examination of Water and Wastewater (1995) 19th edn. American Public Health Association/American Water Works Association/Water Environment Federation, Washington DC, USA

Thaveersi J, Daffonchio D, Liessens B, Vandermeren P, Verstraete W (1995) Granulation and sludge bed stability in upflow anaerobic sludge bed reactors in relation to surface thermodynamics. Appl Environ Microbiol 61:3681-3686

Thaveersi J, Gernaey K, Kaonga B, Boucneau G, Verstraete W (1994) Organic and ammonium nitrogen and oxygen in relation to granular sludge growth in lab-scale UASB reactors. Wat Sci Tech 30(12):43-53

van Lier JB, van der Zee FP, Frijters CTMJ, Ersahin ME (2015) Celebrating 40 years anaerobic sludge bed reactors for industrial wastewater treatment. Rev Environ Sci Bio/Technol 14:681702.

Vanderhaegen B, Ysebaert E, Favere $\mathrm{K}$, van Wambeke M, Peeters T, Pánic V, Vandenlangerbergh V, Verstraete W (1992) Acidogenesis in relation to in-reactor granule yield. Wat Sci Tech 25(7):21-30

Visser A, Alphenaar PA, Gao Y, van Rossum, G, Lettinga G (1993) Granulation and immobilisation of methanogenic and sulfate-reducing bacteria in high-rate anaerobic reactors. Appl Microbiol Biotechnol 40:575-581 
Wang JS, Hu YY, Wu CD (2005) Comparing the effect of bioflocculant with synthetic polymers on enhancing granulation in UASB reactors for low-strength wastewater treatment. Water SA 31:177-182

Yu HQ, Fang HHP (2001) Acidification of mid- and high-strength dairy wastewaters. Water Res 35:3697-3705

Zandvoort MH, van Hullenbusch ED, Gieteling J, Lens PNL (2006) Granular sludge in full-scale anaerobic bioreactors: trace element content and deficiencies. Enz Microb Technol 39:337-346

Zitomer DH, Burns RT, Duran M, Vogel DS (2007) Effect of sanitizers, rumensin and temperature on anaerobic digester biomass. Transactions of the ASABE 50:1807-1813 